\title{
Research \\ Managing Waters of the Paraíba do Sul River Basin, Brazil: a Case Study in Institutional Change and Social Learning
}

\author{
$\underline{\text { Lori M. Kumler }}^{1}$ and Maria Carmen Lemos ${ }^{2}$
}

\begin{abstract}
This article examines the implementation of integrated water-management institutions in the Paraíba do Sul River basin in southeast Brazil. It argues that social learning has been critical in facilitating reform implementation so far, and will likely continue to be an important factor for the future sustainability of the new management system. There has been a synergistic relationship between social learning and Brazil's water-reform hybrid governance institutions, in which social learning facilitated the implementation of the reform's new institutions, which in turn enabled further learning in the context of the river basin committee's decision-making process. Through interviews, surveys, and observations, we identified social-learning capacities, including trust, an ability to work together, and the committee's shared understanding of the institution's problems, possibilities, and mission. Effective management through social learning was demonstrated by the institution's adaptive capacity in the face of a severe drought.
\end{abstract}

Key Words: Brazil; CEIVAP; institutional adaptation; river basin management; social learning; water policy

\section{INTRODUCTION}

Around the world, the issue of water quality and quantity has captured the attention of communities, policy makers, and water managers. Pressured by rapid and poorly planned development and population growth, water scarcity has become a concern even in traditionally water-rich regions such as southeast Brazil. To address these issues, governments and water managers have sought to improve existing managing organizations and institutions to promote more sustainable water use, in many cases, by involving a wider range of stakeholders and by redefining the scale of decision making to the basin level.

Partly motivated to address its water problems and partly as result of widespread political reform, in 1997 the Brazilian government enacted new water resources legislation (Law 9433 or Water Law, for the purposes of this paper), which decentralized management and designed multi-level stakeholder participatory institutions. The Brazilian reform subscribes to many of the tenets of good governance highlighted in the literature with the creation of multiple, redundant, and polycentric scales of management as well as the inclusion of hybrid mechanisms of governance that combine state, market, and community institutions and actors (Ostrom 2001, 2005, Lemos and Agrawal 2006). The centerpiece of the new water management model is the river basin committee composed of representatives from water user groups, government, and organized civil society (see Fig. 1). The committees meet periodically and have among their responsibilities the design and implementation of bulk-water permit and charging systems, approval of river basin management and water zoning plans, and facilitation of conflict resolution among users. To date, over 100 river basin committees have been created in Brazil and are at different stages of evolution (Abers and Jorge 2005). The most controversial aspect of the reform has been the reconceptualization of water as a public good with economic value; that is, under the new law, water users must pay bulk-water charges ("cobrança"for a detailed analysis of the "cobrança" system, see Formiga-Johnsson et al. 2007) and must obtain a permit ("outorga") to use water from the appropriate state or federal water agency. The reform's ultimate goals are to ensure adequate water supplies for the nation's future, to promote rational and integrated 
use of water resources, and to prevent and defend against critical hydrological events (Diário Oficial da União 1997).

Although it has been several years since the passage of the new law, it is still too early to assess many of the long-term outcomes regarding water and institutional sustainability. However, the institutionalization of new forms of management has progressed significantly in a number of basins, and it is possible to explore some of the factors that may have been conducive to a higher or lower rate of success in the implementation of the reform's basic mechanisms. Among the most evolved implementation processes is that of the Paraíba do Sul River River Basin (PSRB), a federal waterway that crosses Brazil's three most-developed states (São Paulo, Rio de Janeiro, and Minas Gerais). In this paper, we analyze the federal committee for the Paraíba do Sul River basin, CEIVAP ("Comitê para Integração da Bacia Hidrográfica do Rio Paraíba do Sul," or Committee for the Integration of the Paraíba do Sul Hydrographic Basin) in light of its faster and perceived more successful implementation process (Formiga-Johnsson et al. 2007). In particular, we examine CEIVAP's actions during a challenging drought period from 1998-2004 and explore the factors that influenced how it responded to the crisis.

What accounts for CEIV AP's ability to implement reform-oriented institutions? Among the many contributing factors, we argue that social learning - defined here as learning through interactionshas been critical in facilitating reform implementation so far, and will likely continue to be an important factor for the future sustainability of the new management system. When successful, social learning may lead to both an improved environment and an increased capability of actors to attain agreement (Pahl-Wostl and Hare 2004). Moreover, social learning has been proposed as a vital element for the implementation of adaptive management and more resilient water systems (Carpenter et al. 2001, Folke et al. 2005, Pahl-Wostl 2006, Ison and Watson 2007, Pahl-Wostl et al. 2007). Although much has been written about the positive role of social learning in water management, the concept remains relatively untested empirically, especially in relation to its dialectical relationship with different institutional/governance mechanisms for natural resources management. In this article, we propose that, in the case of the CEIVAP, there has been a synergistic relationship between social learning and Brazil's water reform hybrid governance institutions in which social learning facilitated the implementation of the reform's new institutions, which in turn, enabled further learning in the context of the river basin committee's decision-making process. In other words, social learning has been both "enabling to" the implementation of water reform institutions and further "enabled by" the implementation of such institutions.

In the next section, we describe the PSRB and the new management system in detail. We then review the literature on social learning, natural resources governance institutions, and water reform in Brazil to build our analytical framework. After describing our research methods, we discuss the interface between the old and new institutional systems in the PSRB. We conclude with a few general lessons from this case that can be used to inform natural resources governance in other regions of Brazil and the world.

\section{The Paraíba do Sul River Basin: Present and Past}

The Paraíba do Sul basin covers an area close to 57 $000 \mathrm{~km}^{2}$ and crosses three states, Rio de Janeiro, Minas Gerais, and São Paulo. The PSRB is home to 5.6 million people and, in addition, supplies water - via a complex diversion and water transfer system - for nearly 8 million residents of the Metropolitan Rio de Janeiro Region ("Metro Rio"), located outside of the basin. In total, 180 municipalities in the basin depend on the Paraíba do Sul for water (Campos 2001), and it is estimated that the basin comprises $13 \%$ of Brazil's gross domestic product (GDP) (Braga et al. 2005).

In the past, water management in the PSRB was mostly carried out in an incremental, piecemeal, and mostly technocratic fashion. Neither was it integrated across governing and social scales; for example, different scales of government authorities granted permits for hydroelectric plants with virtually no coordination: state permits for state waters and federal permits for federal waters (Margulis et al. 2002). Although the notion of integrated management in Brazil had been around since the 1940s, it was not until the1970s that the government took concrete action to create more integrated management institutions (see Fig. 2).

Water allocation and distribution across the basin has been historically a contentious affair. Although the reservoirs are mostly located in the state of São 
Fig. 1. Diagram of National Water Resources System (adapted from: Agência Nacional das Águas, October 2002). Bold boxes indicate organizational elements created after the Water Law.

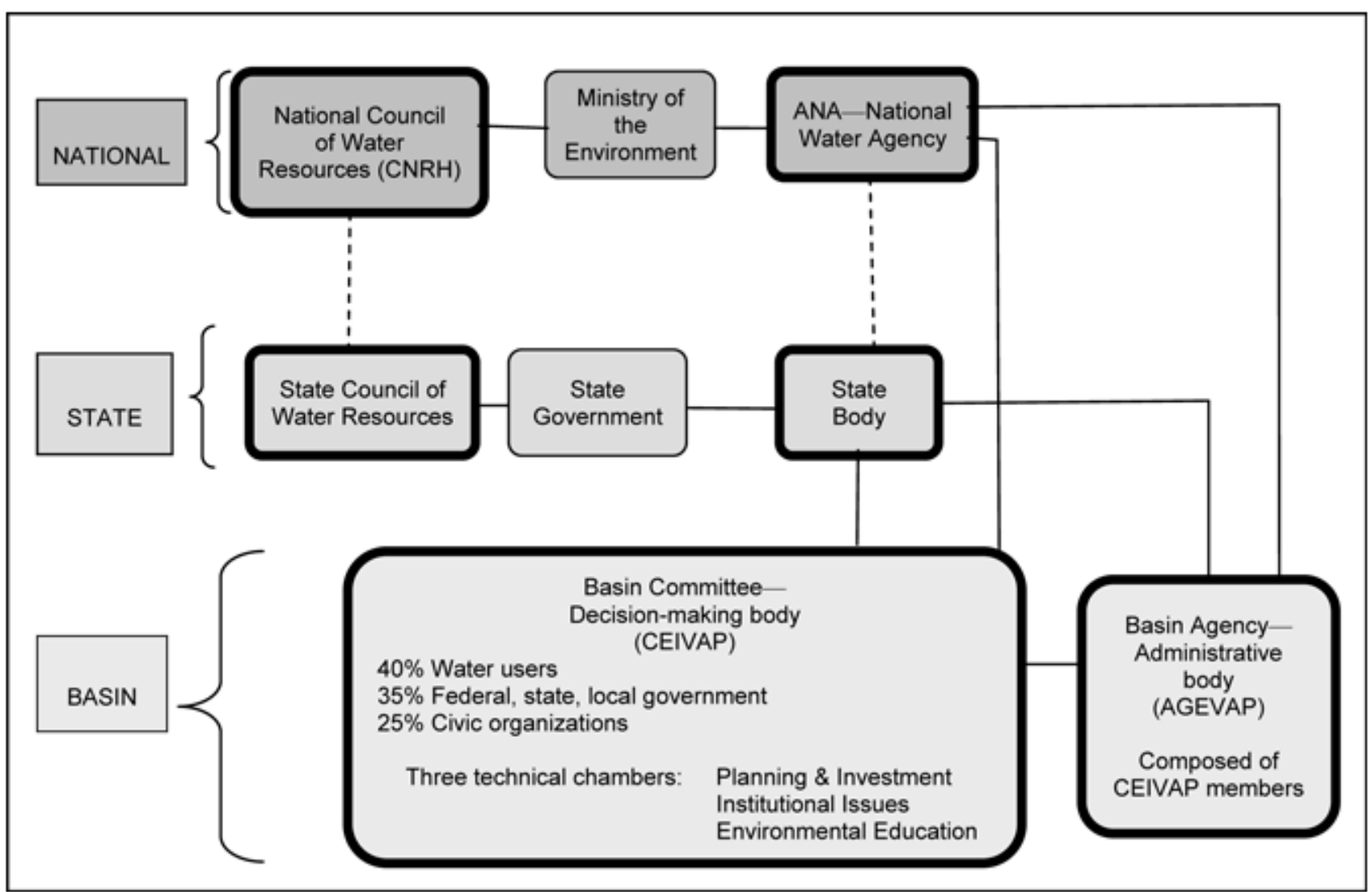

Paulo, two thirds of the flow of the Paraíba do Sul is siphoned off to the Guandu River in the state of Rio de Janeiro to supply Metro Rio. The transfer disproportionately burdens communities in São Paulo state that depend on high water levels in the reservoirs for tourism and recreational purposes. Figure 3 shows the river headwaters and the reservoirs located within São Paulo state. The basin is crucial for domestic water, industries, recreation, and agriculture; its reservoirs and dams historically provided hydropower to the region (Campos 2001).

The river's water committee, CEIVAP, is an important case from a number of perspectives. The basin is one of the most physically complex, with dams and reservoirs built over a time span of nearly a century. Because the river crosses three states and the industrial corridor between Brazil's two largest cities (São Paulo and Rio de Janeiro), it also has political, jurisdictional, and socioeconomic importance. The committee stands out in terms of its implementation because it is the first federal committee to institutionalize the collection of bulkwater fees from users and the first to create a dedicated administrative agency AGEVAP ("Agência do Vale do Paraíba," Paraíba Valley Agency). Moreover, in the past few years, the basin has experienced severe drought events that tested the mettle of CEIVAP. The basin's physical, institutional, and political complexities offer an excellent test case to inform other regions in Brazil and around the world struggling with issues of water management. 
Fig. 2. Water management timeline. Shows the primary federal-, state-, and basin-level events relevant to the CEIVAP case.

Water Management Timeline
1934 Federal Water code is enacted
1945 Creation of the Săo Francisco
hydroelectric company
1978 CEEIVAP created
1987 Salvador Declaration approved by ABRH
1988 Federal constitution is amended to set up
a National Water Management System
1991 -
1997 Seven states reform water management
systems
1996 CEIVAP is created
1997 Federal Water Law enacted
2000 National Water Agency (ANA) created
2003 CEIVAP enacts cobrança

\section{ANALYTICAL FRAMEWORK}

Emerging literature on sustainable common resources management has increasingly suggested that hybrid governance modes-those that span different scales and sectors across the state-marketcommunity divide-not only hold significant promise for long-term resource sustainability but can also potentially promote more democratic and accountable forms of governance (Lemos and Agrawal 2006). Similarly, polycentric and redundant designs are considered essential to sustainability and resilience. Ostrom $(2001,2005)$ argues that polycentric systems outperform monocentric systems in their ability not only to incorporate local knowledge and to adapt to changing conditions (such as climate-driven impacts) but also to provide greater information sharing and accountability. In addition, redundant and overlapping systems contribute to institutional resilience, that is, they increase their ability to weather and recover from crisis (Ostrom 2001). Likewise, Dietz et al. (2003) suggest three principles that contribute to robust (flexible) environmental institutions: involving interested parties in informed discussion of the rules, nesting authority to allow for adaptive governance at various levels, and employing a mixture of institutional types.

Implicit in this flexibility is the need for learning to occur. Over the decades, social learning, defined as learning from others through observation and modeling (Bandura 1973, 1977), has been found to influence and be influenced by the institutions shaping its creation (Stein 1997). Empirical research has identified social learning as critical to the success of the management of systems ranging from floodplain and river restoration to adaptation to climate change and disasters (Paton et al. 2001, 
Fig. 3. Paraíba do Sul River Basin. Enlargement shows primary tributaries, reservoirs, and the Guandu River transfer denoted by a circle. (Source: COPPE at the Federal University of Rio de Janeiro.)

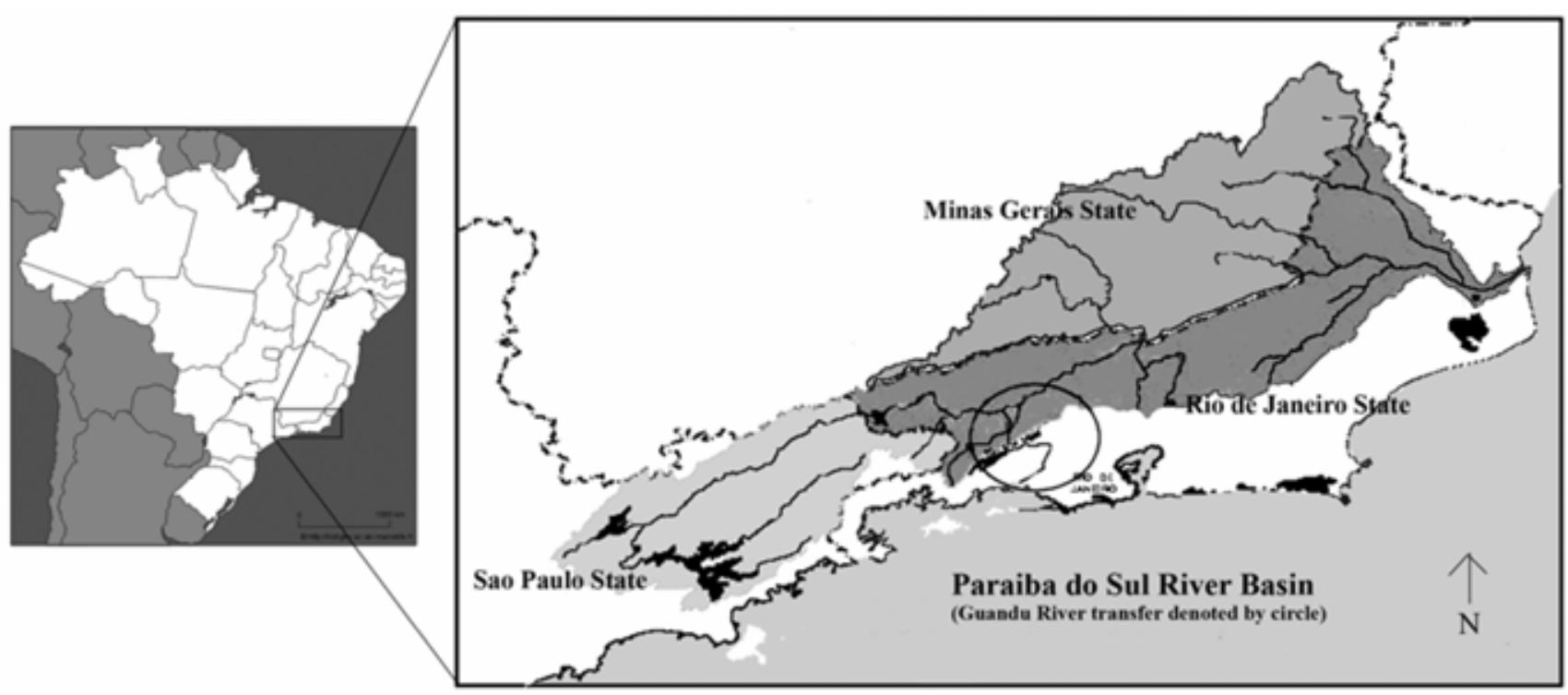

Berkes and Jolly 2002, Pahl-Wostl 2006). Recent work carefully mapping opportunities and constraints for social learning in European countries points toward a promising framework to guide research in this area (Enserink et al. 2007, Ison and Watson 2007, Mostert et al. 2007, Steyaert and Ollivier 2007).

Pahl-Wostl (2002) identifies several critical factors that enhance social learning, including: (a) shared problem perception by actors; (b) the building of trust as a base for critical self-reflection; (c) actor recognition of mutual dependencies and interactions; (d) a reflection on assumptions about the system being managed and on subjective valuation schemes, and (e) actor engagement in collective decision and learning processes. Social learning is an iterative process; both governance structure and the environment affect and are affected by it. In turn, the governance structure and the natural environment being governed affect the process of management. Within this process, actors' social involvement (such as development of social capital or new social practices) and content management (creating new knowledge about the resource or using new management tools such as models) are equally important (Pahl-Wostl and Hare 2004). Ideally, this process results in better technical and relational qualities, and feedback on outcomes is used to re-examine both governance and the environmental contexts.

But although institutional theory and social learning offer valuable insights to understand new forms of environmental governance such as the one analyzed here, they are less useful for examining the actors who work within institutional structures or separating the role of the actors from the role of institutions and the influence of politics. In this context, the ideas and worldviews that guide these actors' behavior are important to define the ways they affect natural resources management and policy making (Lemos 1998, Lemos and Oliveira 2004). Indeed ideas, and previous experiences with social mobilizations, often shape the way social actors adapt institutions and define the range of choice available to stakeholders to affect policy outcome. Such experiences, social networks, and understanding of physical complexities cannot be gained overnight, and the social memory held by experienced actors can be a powerful contributor to institutional resilience (Folke et al. 2005).

In this study, we argue that, in the PSRB, the existing structures of knowledge production and sharing, which were in place long before the water reform, 
facilitated social learning. In turn, the post-reform institutional structure was critical in that it allowed participants to use past social learning and created new opportunities for social learning that enhanced the initial Water Law implementation process in the PSRB.

\section{METHODS}

This research relies on a mixed method approach that includes both qualitative and quantitative data. Qualitative data for this research has been collected over a period of 2 years of intense field research in the PSRB. Methods included (1) in-depth, semistructured interviews of 34 CEIVAP members and key informants in the water management sector, and (2) direct observation of four basin committee meetings: a full CEIVAP "plenária" meeting, a CEIVAP Planning and Investment technical chamber meeting, a CEIVAP ad hoc technical group meeting focused on water levels, and a Guandu River committee meeting. All semi-structured interviews were carried out individually at the subject's place of employment and were recorded, transcribed, and coded. Data were then triangulated and cross-checked for consistency. Subjects were chosen by cold calling a list of CEIVAP members, and subsequently "snowballed" (where subjects were asked to suggest additional interview subjects until most new names are exhausted) from the original sample. Additionally, quantitative data were obtained through the Watermark survey that queried 626 members of 18 river basin committees and consortia (including the PSRB), and was organized around five main modules: participation, representation, worldviews, socioeconomic demographics, and knowledge use. In addition, key informants in each basin were interviewed on subjects ranging from day-to-day committee activities to an assessment of goals accomplished (for full details on methods, see Kumler (2005)).

\section{A VIRTUOUS CYCLE OF LEARNING AND INSTITUTIONAL REFORM: THE IMPLEMENTATION OF CEIVAP}

In this section, we discuss in detail the virtuous cycle of social learning and institutional reform in the Paraíba do Sul basin. First, we explore how existing structures influenced the design and implementation of CEIVAP. Next, we examine how the current structure has created further opportunity for social learning, negotiation, and improved response to crisis.

In terms of continuity, the new system clearly benefited from the old structure to implement the new one. The history of integrated water management in Brazil began in the 1970s, when, in the wake of the 1972 United Nations Conference on Human Environment, several basin committees emerged in Brazil, including one in the PSRB, named the CEEIVAP ("Comitê Executivo de Estudos Integrados da Bacia Hidrográfica do Rio Paraíba do Sul," Executive Committee for the Integrated Studies of the Paraíba do Sul Basin). The CEEIVAP's main role was to support a national initiative to assess water resources in Brazil (Luchini 2000). These committees generally included technocrats from the state and federal levels, but lacked representation from municipalities and civil society. However, they provided one of the first opportunities for stakeholders to start thinking about water reform. They also supported the emergence of a network of water managers who worked together in the region for many years - and began to advocate for water reform.

As the federal government was in the process of preparing and passing the 1997 law, a group of nine CEEIVAP participants began to make the transition to the current CEIVAP (named after its predecessor) between 1996 and 1997 (personal interviews). From a solid core of committee members who had worked in water resources for 10 years or more, six had served on the committee for 6 years or more, and one had actually been on CEEIVAP or CEIVAP since 1981 (personal interviews). In the context of these interactions, they had exchanged ideas and knowledge, shared experiences, and developed much needed social capital to push for reform.

As a new management institution, CEIVAP is a good example of a coordinated polycentric system, with multiple decision-making centers each wielding power. Figure 4 depicts and compares the two systems of management in the PSRB before and after the reform. The old system mostly functioned in an uncoordinated, top-down fashion that lacked formal links and established channels of communication. The new system loosely coordinates and integrates different scales and sectors, creating formal links among actors and jurisdictions where none existed before. For example, institutionally, CEIVAP overlaps with numerous other committees and consortia in the 
basin. This includes the São Paulo committee for the Paraíba do Sul River (in existence prior to CEIVAP), other existing and potential sub-basin committees within each state, and consortia of users and of basins. As we describe below, the significant institutional and actor interactions and redundancy in the new system offer increased opportunities for coordination and information sharing. Under the new law, actors and organizations act in a much more integrated fashion. For example, in addition to obtaining an environmental permit from the environmental agency, IBAMA ("Instituto Brasileiro do Meio Ambiente e dos Recursos Naturais Renováveis," or the Brazilian Institute for the Environment and Renewable Resources), users must also get a water use permit from ANA ("Agencia Nacional das águas," or the National Water Agency for federal waters) or the state management agency (for state waters and groundwater resources), and they must pay for use (withdrawal and consumption) of river water and for discharged effluents, as determined by CEIVAP. Thus, their actions now are constrained by collective decisions regarding water use and water charges. In this case, the synergy between actors and institutions/organizations has been positive, with "técnicos" using their experience to "calibrate" the new institutional mechanisms and, in turn, the new organizational structure pushing "técnicos" to communicate and work together in an integrated fashion.

Although a number of the participants are the same, along with new additions such as ANA and civil society, the power framework within which they operate is different. These two factors-a new power structure and the amalgamation of new and old actors-have helped the process of social learning for CEIVAP as an institution, thus increasing its future potential adaptability and even sustainability. Beyond creating such opportunities for creative problem solving, the structure brings new opportunities for interaction and information flow. Just as organizational and institutional overlap has increased, the actors themselves exhibit a type of redundancy or pluralism in three respects. First, a number of actors who have been involved in managing the river for some time have also been involved in earlier integrated management experiments such as CEEIVAP. These people bring a unique long-term historical perspective as well as considerable experience to the table and are important in accessing "institutional memory" (personal communication). Secondly, a small number of committee members represent more than one sector, such as one member who represents both civil society and government. Such actors undoubtedly see the issues from a variety of angles or frames (Dewulf et al. 2005) and it is likely that they may both enable others to do the same or determine how to approach specific issues with different sectors. Thirdly, several committee members serve on other basin committees. With one exception, from all the members interviewed for this study, committee members felt that this gave them an advantage. According to one respondent, "I think that the existence of the São Paulo committee served to open pathways for us into the federal committee [CEIVAP]" (personal communication).

Previous experience and exchange of knowledge within these networks of técnicos both in the public and private sectors is likely to result in higher levels of synergy across the state-society divide. Additionally, experience accumulated over the years is perceived as a clear advantage since for a first-time participant in the process, getting to know the rules and the topics of discussion "takes a long time" (personal communication). Another advantage mentioned was the ability "to recycle" ideas by bringing an agenda item that might have failed in one river basin committee to another where it may have a better chance of succeeding. For example, in one particular case, when an environmental education idea was rejected in one committee, a dual committee member offered to bring it to another committee (personal communication).

Additionally, because the São Paulo committee and the Guandu River committees, in particular, share significant problems and issues in common with CEIVAP, debating these issues in one committee surely helps when the same issue arises on another committee. And because all the members of the executive agency AGEVAP are also members of CEIVAP, opportunities for similar synergies exist here as well. Thus, in terms of actors, organizations, and committees, the new polycentric and redundant institutional design has created substantial new spaces for social learning.

In interviews with members of the committee, several elements for social-learning capacity identified by Pahl-Wostl and Hare's (2004) framework became evident. In particular, we found that committee members showed significant sharedproblem identification, an awareness of differing perspectives and goals, an ability to learn to work 
Fig. 4. Conceptual decision-making diagram. Decision making by water users on the Paraíba do Sul before and after the new water policy. Arrows represent direction of water-use decision making and coordinated information flow. Ovals in the "After" diagram show committees and are dashed to show that they are open to outside interaction and participation. Notice the committee and membership overlap, streamlined water-use decisions, and enhanced flow of information from the river to committees in the "After" diagram compared with the relatively uni-directional and isolated decision making of the first diagram.

\section{BEFORE}

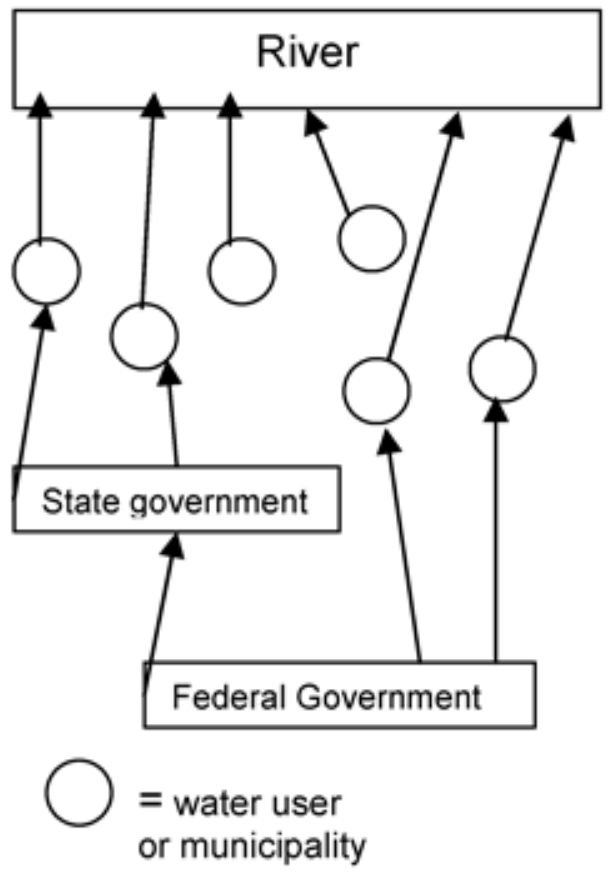

AFTER

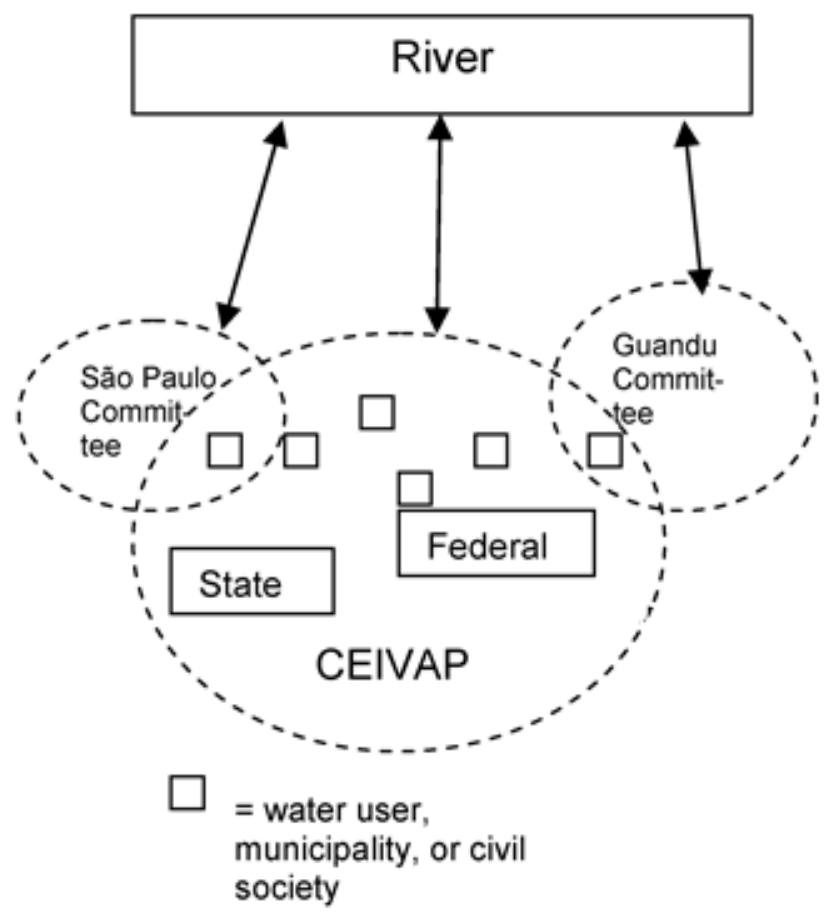

together, an understanding of mutual interdependence, and trust. In addition, we found that two other elements were present: a certain faith in the committee's abilities and a "buying-into" of the system itself.

As shown in Table 1, interview data were complemented by Watermark survey data, observations, and an internal evaluation of CEIVAP by its members in 2004. Survey data show high levels of agreement around both the main basin problems (water quality and environmental degradation) and about the "cobrança" process: $74 \%$ believe that without it, the committee would lose its impetus and become non-sustainable. In addition, $89.2 \%$ of the members believe that users who consume and pollute the most should pay more irrespective of their capacity to pay. They also have high praise for some of the mechanisms created and implemented by the reform: $77.6 \%$ consider the level of democracy in decision making within the committee good or excellent, $63.7 \%$ believe that the Committee attempts to involve all members, and $77.5 \%$ agree that the committee's attempts to resolve conflict are good or excellent. When asked about who sets the Committee's agenda, 46.2\% believe that all who want to get involved do, and although $36.9 \%$ believe that the agenda is set by a 
small group, they also believe this group values the contributions of all members. Only $1.5 \%$ pointed to lack of motivation from members as a problem.

Not surprisingly, the most-reported constraints to success were lack of resources (65.2\%) and conflict $(13.6 \%)$. This is consistent with data from the indepth interviews, in which respondents suggested that conflict among sectors was a critical factor making decisions more difficult. And in many cases, these conflicts dealt with money. In in-depth interviews, five informants indicated that talking about issues of money or the "cobrança" often expose differing perspectives among stakeholders, many times making decisions difficult. One committee member stated, for example, that although calls for more resources are frequent, not all, especially users, agree: "Thus, if I'm a water user, why am I going to want a committee or a basin plan, if after all of this, I'm going to have to pay for the water?" (personal communication).

Although there are internal politics, in-depth interviews showed that committee members share a fundamental consensus in their belief in the system and in their understanding of the committee's role. According to one respondent, "I've never had, and not just here [at this particular meeting], but I've never had a sense that someone is participating on the committee in a contrary way" (personal communication).

What the survey data and the in-depth interviews show is that committee members seem to have adopted a sense of ownership of the process-a process that the vast majority of them buy-into and support, even when pressed on difficult or divisive issues. The level of agreement shown, especially on agenda items of top priority, bodes well for the ability of the committee to work through difficult issues. Not only do they agree on the limitations of CEIVAP's power, but they also agree on the interpretation of the law in terms of payment of transferred water. In addition, with only one dissent, all of those questioned believe that the Water Law is adequate to resolve the problems of water. Just over half of those interviewed for this study felt that it was only a question of having the political will and/or effectively implementing the law. We should note that overall, committee members interviewed are highly educated with more than 5 years of experience in water-resources work. They clearly understood the limits of the natural system and the weaknesses of the man-made system, without which it is unlikely that CEIVAP would be making the progress it has made.

\section{An Early Test: 1998-2004 Drought}

In this section, we examine social learning in action during a challenging period of drought between 1998-2004. When responding to the prolonged drought, committee members showed a high degree of cooperation, integration, flexibility, and even trust, on several fronts. First, when the drought hit hard, it became clear that the larger committee was too unwieldy to make efficient decisions necessary to avoid collapse-so the challenge was to make fast and effective decisions within the new management framework. To address competing needs, CEIVAP formed a working group of "técnicos" both from the private and public sector that met weekly to examine and address system needs and limitations. Whereas in the past, decisions about river flow were mostly controlled by the hydroelectric sector, after the creation of CEIVAP, the pressure to include broader representation of stakeholders increased. The ad hoc group made decisions regarding reservoir and transfer release levels and, although others were welcome, the group was largely formed by "técnicos" (personal observations). As the situation improved, the group met with less frequency and continued to monitor the situation.

The situation was particularly touchy because of the previously described history of the reservoirs and the conflicting needs of São Paulo and Rio de Janeiro states. Although the state of Rio de Janeiro wanted these reservoirs to keep releasing a steady amount of water to regulate water supply and control water quality, São Paulo wanted the release from the reservoirs decreased so that reservoir levels could recuperate. The work group managed to address the drought problem by reducing the reservoir release while carefully monitoring water quality downstream. This also involved physically intervening in the water captured by some cities. The group worked with local authorities to determine critical areas where this capture could not be reduced and others where it could (personal interviews). According to one respondent, "It was a long, complex, and careful operation involving monitoring of water quality of the river" (personal interviews). In these meetings flows were debated and reduced or increased in small increments. In one meeting observed for this research, participants 
Table 1. Social-learning elements identified within CEIVAP by data source.

\begin{tabular}{lccc}
\hline \hline & \multicolumn{2}{c}{ Data source } \\
Social-learning capacities & $\begin{array}{c}\text { In-depth inte- } \\
\text { rviews }\end{array}$ & $\begin{array}{c}\text { Watermark } \\
\text { survey }\end{array}$ & $\begin{array}{c}\text { Onternal su- } \\
\text { rvey }^{\dagger}\end{array}$ \\
\hline Shared problem identification (water quality and finances) & $\mathrm{X}$ & $\mathrm{X}$ & $\mathrm{X}$ \\
Awareness of differing perspectives/goals & $\mathrm{X}$ & $\mathrm{X}$ & $\mathrm{X}$ \\
Ability to learn to work together & $\mathrm{X}$ & $\mathrm{X}$ & $\mathrm{X}$ \\
Understanding of mutual interdependence & $\mathrm{X}$ & $\mathrm{X}$ \\
Trust & $\mathrm{X}$ & $\mathrm{X}$ & $\mathrm{X}$ \\
Faith in committee's abilities & $\mathrm{X}$ & $\mathrm{X}$ & $\mathrm{X}$ \\
Drought response & $\mathrm{X}$ & & \\
\hline
\end{tabular}

† Internal survey conducted by AGEVAP, not part of authors’ fieldwork (CEIVAP 2004).

recommended that the transfer pumping to the Guandu River be increased from $160 \mathrm{~m}^{3} / \mathrm{s}$ to $165 \mathrm{~m}^{3} /$ s. The outcome of the group's work was the successful recuperation of the reservoirs while managing to meet water needs in Rio as well.

This success created goodwill on many fronts. The various users ably worked together to reach an acceptable solution, one which could not have been completed without involvement and cooperation on many levels. The operation was so successful that some believe the possibility of reservoirs reaching dangerously low levels is almost non-existent; according to one "técnico": "I don't believe in the possibility of the reservoirs emptying because of the methods being adopted" (personal communication). Another indicated that because of this action a return to previous high levels of transfer pumping would be unlikely (personal communication). In other words, it became clear that the city of Rio de Janeiro could survive with less flow.

\section{THE FUTURE OF CEIVAP AND THE THREAT OF POLITICS}

As mentioned in CEIVAP's historical background, key individuals pushing for water reform over the years were central agents in implementing the new system. Recent developments in the basin, however, may threaten its stability and long-term sustainability. In particular, can the success of a system lead to its demise, as individual actors see an opportunity to gain political capital? In CEIVAP's case, for example, the political maneuvering of one mayor (and member of CEIVAP) seeking to bolster his political clout visà-vis the CEIVAP and AGEVAP has threatened to undermine the committee's long-term effectiveness. His attempts to influence the distribution of managing positions within the Committee at the expense of representatives of other states and civil society organizations has been met with disappointment among CEIVAP members, which, if left unchecked may result in demobilization (personal communication). It remains to be seen whether other positive elements such as polycentrism and redundancy can allow CEIVAP to weather such threats over the longer term.

As the dynamics of the committee change and new actors replace current ones, some of the social capital and expertise will go with them. Because a number of committee members have been involved since the beginning of the process, they bring perspectives that cannot be recreated. On the other 
hand, these actors may be less willing to accept innovations that newer actors might embrace, thereby making the system less flexible. However, at this crucial juncture of CEIVAP's early years, strong, experienced members may help to fortify the institution. Once it is established, the eventual influx of newer, younger participants may help bring in innovations just when greater flexibility will be necessary to keep up with changing external factors affecting water management and use. Although actors' behavior can be unpredictable, it is important for institutions to be able to function when old actors leave and new ones enter and, in some contexts, actors may be more important than the institutions that house them. This may be especially true early on in an institution's history when actors might have been involved in the founding of the institution itself, thus bringing with them a certain level of "buy-in" and energy that later actors might not have. Such actors may also be important to the processes of social learning by providing much needed experience and knowledge, by providing a sense of continuity, and by participating in policy networks pushing for reform. Although we can identify factors that seem to enhance social learning and resilience, much work remains to be done on understanding the relative importance of such factors in resilience-especially vis-a-vis the role of power (Mostert et al. 2007).

\section{CONCLUSIONS}

Significant changes in society and politics in Brazil over the past 20 years have enabled progress toward integrated water management in several regions. In the case of the Paraíba do Sul basin and its federal committee, CEIVAP, the framework of social learning has much to contribute to understanding the process of implementation. The changing nature of state-society relations, the institutional structure, the role of actors and networks, and actor trust and buy-in to the system have all enhanced social learning. In the case of the PSRB, such social learning has enabled CEIVAP to implement the federal law while allowing for local adaptation.

The new Water Law enabled CEIVAP to absorb experience and social capital while creating new spaces for social learning and, at the same time, expanding the process to include previously excluded stakeholders. This inclusive model enables diverse alliances to be forged between sectors that previously would not have been possible, thereby also increasing circulation of information among stakeholders. The pluralism of the actors increases social networks both within and outside of CEIVAP, helping to generate social learning within the basin and potentially even outside of it. Institutional redundancy on several levels strengthened information creation, information sharing, and networks. The flexibility of the system is demonstrated by the ad hoc work group and its contribution to sustainable use of water during a severe drought event.

The combination of this trust-based network and CEIVAP's concrete successes in terms of collecting and applying "cobrança" money, creating a basin agency, and averting disaster in the face of a crisis has resulted in a strong buy-in to the system. Members also exhibit a high degree of trust in technical capacities and abilities.

This study is limited to the initial implementation process; with the drought crisis past and as the process continues to unfold, new challenges will also emerge. Already, results of this study highlight several problems that face CEIVAP. Clearly, actors who have been involved for decades have had more time for social learning. This likely explains interview results where civil society actors, who tend to be new to the management process, were perceived as being least effective in their attempts to represent their sector. If not remedied, this could undermine trust and the legitimacy of the system. The committee might consider engaging in team building and training to attempt to "even out" the playing field in this regard.

The issue of financial resources is a difficult issue that permeates many decisions, and social learning has less impact here. Without money, neither CEIVAP nor the river will be sustainable in the future. Although CEIVAP has seen some financial successes, ultimately money is part of a much larger economic system over which CEIVAP wields very little control. Within the committee, however, the combination of political and economic interests of members may be a crucial balance that assists in institutional evolution. Finally, political meddling may make CEIVAP a victim of its own success.

This study of CEIVAP holds several lessons for other river basins and institutions. First, an inclusive institutional framework that allows previous networks, experiences, and actors to play a role may help to enhance social learning within the new 
framework. Second, early events within the institution can be important to establish trust and buy-in among actors that can set the tone and determine the success of institutional implementation and progress (in CEIVAP's case, early successes during the drought and "cobrança" debate set a positive tone among actors). Third, institutional overlap and actor redundancy can create new sociallearning spaces and policy opportunities within the larger structure and can increase information flow among actors and organizations. Our study also shows that the individual actors matter, especially in terms of their previous institutional experience and knowledge, their relationships with each other, and their buy-in to their roles within the new institution. Finally, issues related to financial resources and politics are perhaps the greatest challenge to such nascent institutions and as such may potentially derail successes. Although our study took place in a developing-country context, many commonalities are evident with studies in European basins (Enserink et al. 2007, Ison and Watson 2007, Mostert et al. 2007), perhaps suggesting that hope exists for social learning and sustainability commonly shared.

Responses to this article can be read online at:

http://www.ecologyandsociety.org/voll3/iss2/art22/responses/

\section{Acknowledgments:}

Funding of this research include grants from NSF (Award \#SES 0233961) and NOAA (Award \#NA03OAR4310010).

\section{LITERATURE CITED}

Abers, R. and K. D. Jorge. 2005. Descentralização da gestão da água: por que os comitês de bacia estão sendo criados? Ambiente \& Sociedade [online] 8 (2):99-124. [online] URL: http://www.scielo.br/sci elo.php?pid $=$ S1414-753X2005000200006\&script $=$ sci arttext.

Agencia Nacional das águas. 2002. The evolution of water resources management in Brazil. [online] URL: http://www.ana.gov.br/ingles/Portais/04-evolution. $\underline{\text { html. }}$.
Bandura, A. 1973. Aggression: a social learning analysis. Prentice-Hall, Englewood Cliffs, New Jersey, USA.

Bandura,A. 1977. Social learning theory. PrenticeHall, Englewood Cliffs, New Jersey, USA.

Berkes, F., and D. Jolly. 2002. Adapting to climate change: social-ecological resilience in a Canadian Western Arctic community. Conservation Ecology 5(2): 18. [online] URL: http://www.ecologyandsoc iety.org/vol5/iss2/art18/.

Braga, B. P. F., C. Strauss, and F. Paiva. 2005. Water charges: paying for the commons in Brazil. International Journal of Water Resources Development 21(1):119-132.

Campos, J. D. 2001. Cobrança Pelo Uso Da água Nas Transposições Da Bacia do Rio Paraíba do Sul Envolvendo o Setor Elétrico. Thesis, Universidade Federal do Rio de Janeiro, COPPE, Brazil.

Carpenter, S., B. Walker, J. M. Anderies, and N. Abel. 2001. From metaphor to measurement: resilience of what to what? Ecosystems 4(8):765781.

Comitê para Integração da Bacia Hidrográfica do Rio Paraíba do Sul (CEIVAP). 2004. Resultado da Avaliação Realizada pelos Membros do CEIVAP. [online] URL: http://www.ceivap.org.br/downloads/ ResultadoAvaliacao.pdf.

Dewulf, A., M. Craps, R. Bouwen, T. Taillieu, and C. Pahl-Wostl. 2005. Integrated management of natural resources: dealing with ambiguous issues, multiple actors and diverging frames. Water Science and Technology 52(6):115-124.

Diário Oficial da União. 1997. Lei no. 9.433, de 8 de janeiro de 1997. [online] URL: http://www.ana. gov.br/Institucional/Legislacao/leis/Lei9433.htm.

Dietz, T., E. Ostrom, and P. C. Stern. 2003. The struggle to govern the commons. Science $\mathbf{3 0 2}$ (5652):1907-1912.

Enserink, B., M. Patel, N. Kranz, and J. Maestu. 2007. Cultural factors as co-determinants of participation in river basin management. Ecology and Society 12(2): 24. [online] URL: http://www.e cologyandsociety.org/vol12/iss2/art24/. 
Folke, C., T. Hahn, P. Olsson, and J. Norberg. 2005. Adaptive governance of social-ecological systems. Annual Review of Environmental Resources 30:441-473.

Formiga-Johnsson, R., L. M. Kumler, and M. C. Lemos. 2007. The politics of bulk water pricing in Brazil: lessons from the Paraiba do Sul River Basin. Water Policy 9:87-104.

Ison, R., and D. Watson. 2007. Illuminating the possibilities for social learning in the management of Scotland's water. Ecology and Society 12(1): 21. [online] URL: http://www.ecologyandsociety.org/voll2/ iss1/art21/.

Kumler, L. M. 2005. Old institutions and new approaches to sustainability: creative cooperation in managing waters of the Paraíba do Sul Basin. Thesis, University of Michigan, Ann Arbor, Michigan, USA. [online] URL: http://www.marcad agua.org.br/teses.htm.

Lemos, M. C. 1998. The politics of pollution control in Brazil: state actors and social movements cleaning up Cubatão. World Development 26(1):7587.

Lemos, M. C., and A. Agrawal. 2006. Environmental governance. Annual Review of Environment and Natural Resources 31(3):1-29.

Lemos, M. C., and J. L. Oliveira. 2004. Can water reform survive politics? Institutional change and river basin management in Ceará, northeast Brazil. World Development 32(12):2121.

Luchini, A. M. 2000. O Arranjo Institucional Proposto Para a Gestão Dos Recursos Hídricos Da Bacia Hidrográfica do Rio Paraíba do Sul. [online] URL: http://www.ead.fea.usp.br/cad-pesq/arquivos/ c12-art07.pdf.

Margulis, S., G. Hughes, M. Gambrill, and L. G. Azevedo. 2002. Brazil: managing water quality: mainstreaming the environment in the water sector. World Bank, Washington, D.C., USA.

Mostert, E., C. Pahl-Wostl, Y. Rees, B. Searle, D. Tàbara, and J. Tippett. 2007. Social learning in European river-basin management: barriers and fostering mechanisms from 10 river basins. Ecology and Society 12(1): 19. [online] URL: http://www.e cologyandsociety.org/vol12/iss1/art19/.
Ostrom, E. 2001. Vulnerability and polycentric governance systems. International Human Dimensions Programme Update 1-2-4.

Ostrom, E. 2005. Understanding institutional diversity. Princeton University Press, Princeton, New Jersey, USA.

Pahl-Wostl, C. 2002. Towards sustainability in the water sector-the importance of human actors and processes of social learning. Aquatic Sciences 64 (4):394-411.

Pahl-Wostl, C. 2006. The importance of social learning in restoring the multifunctionality of rivers and floodplains. Ecology and Society 11(1): 10. [online] URL: http://www.ecologyandsociety.org/voll1/ iss1/art10/.

Pahl-Wostl, C., M. Craps, A. Dewulf, E. Mostert, D. Tabara, and T. Taillieu. 2007. Social learning and water resources management. Ecology and Society 12(1). [online] URL: http://www.ecologyan dsociety.org/vol12/iss2/art5/.

Pahl-Wostl, C., and M. Hare. 2004. Processes of social learning in integrated resources management. Journal of Community and Applied Social Psychology 14(3):193-206.

Paton, D., M. Millar, and D. Johnston. 2001. Community resilience to volcanic hazard consequences. Natural Hazards 24(2):157-169.

Stein, J. 1997. How institutions learn: a sociocognitive perspective. Journal of Economic Issues 31(3):729-740.

Steyaert, P., and G. Ollivier. 2007. The European water framework directive: how ecological assumptions frame technical and social change. Ecology and Society 12(1). [online] URL: http://w ww.ecologyandsociety.org/vol12/iss1/art25/. 